\title{
Interstitial Cell of the Pineal Gland
}

National Cancer Institute

\section{Source}

National Cancer Institute. Interstitial Cell of the Pineal Gland. NCI Thesaurus. Code

C32872.

A non-neuronal cell that supports the pineal gland. It resembles an astrocyte and is found around blood vessels and among groups of pinealocytes. The nucleus is small, elongated and darkly stained. 